\title{
CLINICAL AND EPIDEMIOLOGICAL FEATURES OF AIDS/TUBERCULOSIS COMORBIDITY
}

\author{
Alice Tung Wan Song, Denise Schout, Hillegonda Maria Dutilh Novaes and Moisés \\ Goldbaum
}

SONG ATW et al. - Clinical and epidemiological features of AIDS/tuberculosis comorbidity. Rev. Hosp. Clín. Fac. Med. S. Paulo 58(4):207-214, 2003.

Considering the relevance of AIDS/tuberculosis comorbidity worldwide, especially in Brazil, this study was developed to describe the clinical and epidemiological features of the comorbid cases identified from 1989 to 1997 by the epidemiology service of the Hospital das Clínicas of the Universidade de São Paulo.

METHODS: Databases containing information on all identified AIDS/tuberculosis cases cared for at the hospital were used to gather information on comorbid cases.

RESULTS: During the period, 559 patients were identified as presenting with AIDS/tuberculosis comorbidity. Risk behavior for AIDS was primarily heterosexual contact (38.9\%), followed by intravenous drug use (29.3\%) and homosexual/ bisexual contact (23.2\%). Regarding clinical features, there were higher rates of extrapulmonary tuberculosis when compared to tuberculosis without comorbidity. There was an increase in reporting of AIDS by ambulatory units during the period. Epidemiologically, there was a decrease in the male/female ratio, a predominance in the 20 to 39 year-old age group, and a majority of individuals who had less than 8 years of schooling and had low professional qualifications.

CONCLUSIONS: High rates of AIDS/tuberculosis cases at our hospital indicate the need for better attention towards early detection of tuberculosis, especially in its extrapulmonary form. Since the population that attends this hospital tends to be of a lower socioeconomic status, better management of AIDS and tuberculosis is required to increase the rates of treatment adherence and thus lower the social costs.

DESCRIPTORS: AIDS. Tuberculosis. Comorbidity. Epidemiology. Epidemiological Surveillance.

During the past few years, explosive growth has occurred in emerging and reemerging diseases, such as AIDS and tuberculosis, due to multiple factors, including environmental changes, insufficient public health systems, and social and economic changes.

The dynamics of tuberculosis have changed since the start of the AIDS epidemic in 1981. The disease has reappeared at unexpected levels in developed countries where the incidence used to be low. Rates have also increased significantly in developing countries where the disease was already considered a public health problem.
Despite the new and efficient antiretroviral therapy protecting patients from opportunistic infections, tuberculosis remains a significant problem with HIV infection ${ }^{1}$.

The increased incidence of AIDS/ tuberculosis comorbidity is primarily due to the following: HIV can easily reactivate a latent mycobacterial infection, acquired tuberculosis infection rapidly progresses in an $\mathrm{HIV}$-infected

From the Department of Preventive Medicine, Epidemiology Service, Hospital das Clínicas, Faculty of Medicine, University of São Paulo.

Received for publication on October 16, 2002. individual, and exogenous re-infection occurs ${ }^{1}$. A study conducted in New York ${ }^{2}$ found that $30.0 \%$ of seronegative individuals acquired $\mathrm{Myco}$ bacterium tuberculosis infection after exposure; $3.0 \%$ became infected in the first year after exposure.

Seropositive patients face higher risks of developing tuberculosis. The risk of reactivation of a latent mycobacterial infection increases from approximately 0.07 to 0.1 cases per 100 patients for seronegative individuals compared to with 9.7 to 10.4 cases per 100 patients for the HIV seropositive group $^{2}$.

Tuberculosis is the most important 
opportunistic infection for HIV-infected individuals ${ }^{3}$. In the recent AIDS epidemic in sub-Saharan countries with efficient reporting systems, tuberculosis cases doubled or even tripled in a short period of 10 years ${ }^{4}$. In these countries, $60.0 \%$ of children and $70.0 \%$ of adults are seropositive for HIV; the average death rate is $50.0 \%$ in 18 months $^{5}$. The AIDS/tuberculosis association has also been observed throughout the world. In New York, tuberculosis patients are found to be seropositive for HIV more frequently than in the general population; in Asia, incidence of tuberculosis has increased due to the rapid HIV dissemination, and it is estimated that approximately 1.3 million adults are coinfected by both agents ${ }^{4}$.

The epidemiology of AIDS in Brazil shows high rates of association with tuberculosis. Annual tendencies indicate a statistically significant decline of all AIDS related opportunistic complications, including candidiasis, tuberculosis, pneumocystosis, pneumonia, cerebral toxoplamosis, Kaposi's sarcoma, cryptococcal meningitis, and protozoal infections ${ }^{6}$; however, an increased incidence of tuberculosis has been noticed in the Northeast and Centrowest regions of the country.

From 1980 to 1997, oral candidiasis was the most prevalent AIDS-related opportunistic infection in the State of São Paulo (59.9\%), while tuberculosis represented $32.5 \%$ of opportunistic infections. The pulmonary form of the disease was found in $19.2 \%$ of the patients, while disseminated, extrapulmonary or noncavitary tuberculosis were found in $13.3 \%$ of the cases? ${ }^{7}$.

HIV infection modifies the epidemiological and clinical manifestations of tuberculosis. Seropositive individuals present an atypical pattern with uncommon radiologic findings, and in many cases diagnosis is only made at necropsy ${ }^{8}$. Moreover, tuberculosis in- creases the susceptibility to other opportunistic infections as well as mortality rates ${ }^{9}$.

Given the relevance of the AIDS/ tuberculosis comorbidity worldwide and in Brazil, this study was conducted to describe the clinical and epidemiological features of these cases identified from 1989 to 1997 at our hospital.

\section{METHODS}

Hospital das Clínicas of the Universidade de São Paulo is the largest medical center in Latin America and is considered a tertiary center of reference for the health system of the metropolitan São Paulo area. Since 1988, the hospital's epidemiology service has been responsible for the investigation of reportable diseases identified at the hospital. Data from reported cases produced by this service made this study possible.

Confirmed AIDS/tuberculosis cases were analyzed according to the case definitions standardized by the "Ministério da Saúde"10, 11 (Health ministry)

The study was based on 2 data banks containing information on all the reported AIDS/tuberculosis cases cared for at the hospital. A specific data bank was created to analyze the subgroup of patients found in both original banks. Information registered in the epidemiological reporting forms that populated the data banks included name, gender, street address, district and city of residence, hospital admission date, hospital unit that reported the case, clinical form of tuberculosis, case development, and hospital discharge date.

The period of 1989 to 1997 was selected to avoid the influence of the changes in AIDS case definition criteria introduced by CRT-AIDS in 1998.

Additional information was added to the original data banks from notification files and computerized laboratory data to enhance the clinical and epidemiological description of AIDS/ tuberculosis comorbidity.

The additional information included occupation, educational level, date of AIDS and tuberculosis diagnosis, diagnostic criteria for both diseases, result of PPD (purified protein derivative of tuberculin) test, previous treatment for tuberculosis, associated diseases, date of initiation of treatment for tuberculosis, results of laboratory tuberculosis diagnostic tests (direct bacilloscopy - acid fast smear microscopy, mycobacterial culture and immunohistochemistry), date of the beginning of symptoms, and risk factors for HIV transmission. A special form was created to collect the complementary information. However, some newly gathered information was incomplete due to lack of recording of the information on the epidemiological reporting forms. Therefore, pieces of information such as PPD, associated diseases, outcome, and date of beginning of symptoms were excluded from the study.

\section{RESULTS AND DISCUSSION}

From 1989 to 1997, 559 AIDS/tuberculosis comorbidity patients were found. These cases represented $19.5 \%$ of the total of tuberculosis cases and $20.7 \%$ of the total of AIDS cases in this period. The number of AIDS cases increased until 1995 (Table 1), followed by a decrease in 1996 and 1997. The numbers did not match the expected increasing tendencies, and this can be explained by inadequate reporting from ambulatory units during these years.

The main limitations of this project involved the use of preexistent data banks. The results may not express the universe of cases cared for in the hospital during the period, be- 
cause information was extracted from data containing only the reported cases and was subject to routine assessment problems. Furthermore, changes in the form of assistance may also have produced nonmeasurable variations due to inadequate control. The standardized tuberculosis reporting form used in 1989 and 1990 gathered only information about patient identification and some laboratory results.

Regarding risk behavior for HIV infection, $71.2 \%$ of the patients were heterosexuals, $20.8 \%$ were homosexuals, and $8.0 \%$ were bisexuals. Thirtythree percent mentioned intravenous drug addiction, and $7.9 \%$ had blood transfusions after 1981. The use of intravenous drugs is associated not only with HIV infection, but also with tuberculosis, according to a study conducted in Amsterdam ${ }^{12}$, which found a 6-fold increase in risk of acquiring tuberculosis for HIV seronegative intravenous drug users, while a 13-fold increase was found for seropositive drug users.

The risk factors for HIV among heterosexuals (Table 2) were intravenous drug use (20.2\%), an HIV seropositive or AIDS patient as sexual partner (13.7\%), multiple sexual partners (12.3\%), promiscuous sexual partner (7.9\%), and intravenous drug-addicted sexual partner (4.3\%).

Many individuals had multiple risks for HIV infection; thus, a hierarchical sequence of the manner of HIV transmission was adopted, according to UNAIDS (The Joint United Nations Programme on HIV/AIDS) ${ }^{13}$. The risk factors that presumably led to HIV infection were distributed as seen in Figure 1: $38.9 \%$ acquired the infection through heterosexual contact, $29.3 \%$ through intravenous drug use, $23.2 \%$ through homosexual or bisexual contact, $5.0 \%$ through blood transfusion, and $3.6 \%$ through vertical transmission.

Three hundred and sixty-seven cases were identified on admission at the hospital; the death rate for these patients was $30.5 \%$. These cases represented $65 \%$ of comorbid cases diagnosed at the time of hospital admission, indicating failure of early detection of the diseases.

The distribution of reported cases of AIDS by source of identification and selected periods (1989 to 1991, 1992 to 1994 , and 1995 to 1997 ) is shown in Figure 2. The significant increase in cases reported by ambulatory units (4.0\% in $1989-1991,56.0 \%$ in $1992-$ 1994, and $58.0 \%$ in 1995-1997) is due to the initiation of a specialized ambulatory unit for AIDS ("Casa da AIDS") and to the enhanced information-gathering routine developed by the hospital epidemiology service. Hospital assistance routines may influence the information-gathering needs

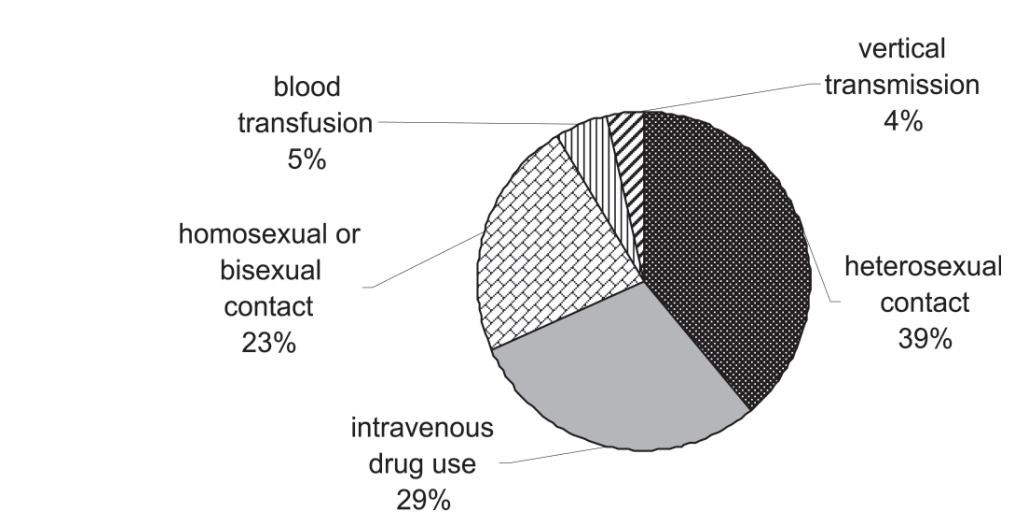

Figure 1 - Comorbidity cases by risk factor for HIV infection - HCFMUSP, 1989 to 1997.

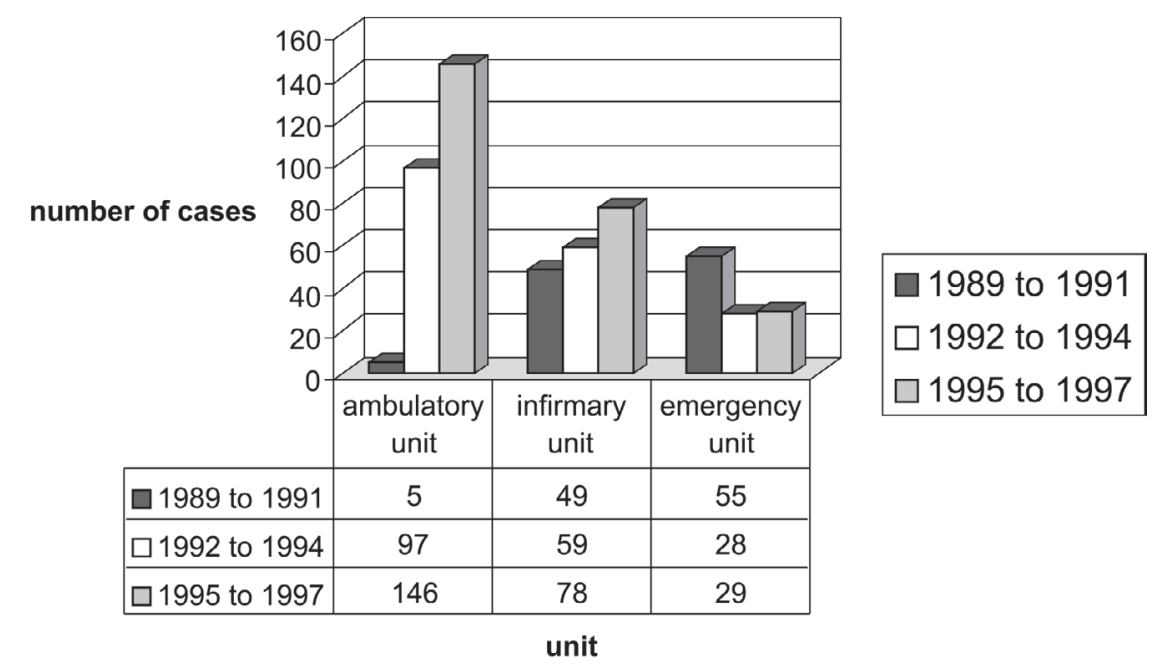

Figure 2 - Aids comorbidity cases by source of notification - HCFMUSP, 1989 to 1997.

(especially from ambulatory units) and the overall reporting process.

Gender distribution (Table 1) showed a male predominance during the whole period. When comparing

Table 1 - Aids/tuberculosis comorbidity cases by gender HCFMUSP, 1989 to 1997.

\begin{tabular}{lrrcr}
\hline \multicolumn{5}{c}{ Gender } \\
Year & \multicolumn{1}{c}{ F } & M & M/F ratio & Total \\
\hline 1989 & 6 & 23 & 3.8 & 29 \\
1990 & 10 & 31 & 3.1 & 41 \\
1991 & 8 & 33 & 4.1 & 41 \\
1992 & 8 & 51 & 6.4 & 59 \\
1993 & 13 & 46 & 3.5 & 59 \\
1994 & 20 & 43 & 2.2 & 63 \\
1995 & 21 & 96 & 4.6 & 117 \\
1996 & 33 & 62 & 1.9 & 95 \\
1997 & 17 & 38 & 2.2 & 55 \\
Total & 136 & 423 & 3.1 & 559 \\
\hline
\end{tabular}


the median of the male:female ratio during the first 5 years with that during the last 4 years, the results are $4: 1$ and $2: 6$, respectively. This variation could be attributed to the changes in AIDS epidemiological scenario in the State of São Paulo, where higher rates of infection of women led to an increased incidence in the heterosexual population ${ }^{14}$. This occurrence has also been found in other countries, such as Puerto Rico, where the proportion of HIV-infected women doubled during the 1980s and the 1990s.

Regarding age (Table 3), $72.5 \%$ of the patients were 20 to 39 years old, the prime working age. This pattern reflects that observed in other studies, such as one conducted in Africa ${ }^{16}$, where the majority of the comorbid cases occurred from ages 20 to 40 years. A peculiar finding was that children from 0 to 4 years old accounted for $2.9 \%$ of cases $(1.6 \%$ in the 0 - to 1 year-old age group), surpassing the next age groups up to the 19-year-old group, thus demonstrating the importance of vertical transmission. This finding is an indicator of the increasing occurrence of AIDS in women. These findings match the data from the State of São Paulo ${ }^{17}$, where the same age group accounted for $2.9 \%$ of cases during the same period.

Regarding educational level, $56.8 \%$ had less than 8 years of schooling, and only $7.2 \%$ had a college degree (Table 4). This finding may either reflect the increasing tendencies of pauperism observed among the affected patients, frequently mentioned in literature ${ }^{13}$, or the usual demand of our hospital. In another study conducted in Brazil (Belo Horizonte) ${ }^{6}$, a higher incidence of AIDS/tuberculosis comorbidity was observed in individuals who spent less than 8 years in school; the author related this finding to more difficult access to antiretroviral therapy and chemoprophylaxis for this segment of the population.
Regarding occupation, $36.8 \%$ of the patients (210/559) had service-related jobs, such as maids, drivers, general helpers, hairdressers, waiters, or construction workers, showing a lower professional qualification, which matched the amount of schooling (data not shown).

Most patients $(81.6 \%)$ lived in the
City of São Paulo, and 15.9\% lived in the metropolitan area surrounding the city. Among those living in the city, about $18.0 \%$ lived out of the hospital coverage area as defined by the Emergency Medical Assistance Integrated Program developed for the São Paulo metropolitan area.

Table 2 - Aids/tuberculosis comorbidity cases by heterosexual risky behavior HCFMUSP, 1989 to 1997.

\begin{tabular}{lrr}
\hline Risky behavior & $\mathrm{N}$ & $\%$ \\
\hline none & 90 & 35.4 \\
intravenous drug use & 56 & 22.0 \\
sexual partner with HIV/AIDS & 38 & 15.0 \\
multiple sexual partners & 34 & 13.4 \\
promiscuous sexual partner & 22 & 8.7 \\
intravenous drug addict sexual partner & 12 & 4.7 \\
bisexual sexual partner & 1 & 0.4 \\
all & 1 & 0.4 \\
Total $*$ & 254 & 100.0
\end{tabular}

* 23 heterosexual patients with unknown risky behavior

Table 3 - Aids/tuberculosis comorbidity cases by gender and age - HCFMUSP, 1989 to 1997.

\begin{tabular}{lrrrr}
\hline & \multicolumn{2}{c}{ Gender } & & Total \\
Age & F & M & N \\
\hline 0 a 4 years & 8 & 8 & 16 & 2.9 \\
5 to 9 years & 2 & 2 & 4 & 0.7 \\
10 to 14 years & - & 4 & 4 & 0.7 \\
15 to 19 years & 2 & 6 & 8 & 1.4 \\
20 to 24 years & 21 & 46 & 67 & 12.0 \\
25 to 29 years & 33 & 84 & 117 & 20.9 \\
30 to 34 years & 31 & 103 & 134 & 24.0 \\
35 to 39 years & 15 & 42 & 67 & 15.6 \\
40 to 44 years & 12 & 28 & 31 & 10.7 \\
45 to 49 years & 3 & 14 & 18 & 5.5 \\
50 to 54 years & 4 & 3 & 6 & 3.2 \\
55 to 59 years & 3 & 5 & 7 & 1.1 \\
$>=60$ years & 2 & 423 & 559 & 1.3 \\
Total & 136 & & & 100.0 \\
\hline
\end{tabular}

Table 4 - Aids/tuberculosis comorbidity cases by gender and schooling level HCFMUSP, 1989 to 1997.

\begin{tabular}{lrrrr}
\hline & \multicolumn{2}{c}{ Gender } & \multicolumn{2}{c}{ Total } \\
Schooling level & $\mathrm{F}$ & $\mathrm{M}$ & $\mathrm{N}$ & \multicolumn{1}{c}{} \\
\hline illiteracy & 3 & 3 & 6 & 1.5 \\
less than 8 years & 55 & 167 & 222 & 56.8 \\
8 years & 16 & 59 & 75 & 19.2 \\
9 to 11 years & 9 & 30 & 39 & 10.0 \\
more than 11 years & 3 & 11 & 28 & 7.2 \\
minor & 10 & 295 & 391 & 5.4 \\
Total * & 96 & & & 100.0 \\
\hline
\end{tabular}

* 168 patients with unknown schooling level 
The pulmonary form of tuberculosis accounted for $73.0 \%$ of all forms of tuberculosis cases (ranging from $63.3 \%$ in 1991 to $81.1 \%$ in 1995 ) and $63.4 \%$ of tuberculosis in seropositive patients (ranging from 50.0\% in 1992 to $74.4 \%$ in 1993) (Table 5). Meanwhile, the extrapulmonary form represented $27.0 \%$ of the cases of tuberculosis without AIDS (ranging from $18.9 \%$ in 1995 to $36.7 \%$ in 1991) and increased to $36.6 \%$ in the comorbid group. Although statistical analysis was not applied to the numbers, extrapulmonary tuberculosis appears to occur more frequently in seropositive individuals. A greater involvement of extrapulmonary structures in HIVpositive tuberculosis patients due to hematogenous mycobacterial dissemination is described in the literature ${ }^{18}$. The lymph nodal and disseminated forms accounted for $36.7 \%$ and $30.5 \%$ of extrapulmonary tuberculosis, respectively.

Of 559 patients, 14 (2.3\%) presented 2 episodes of tuberculosis during the period of study: 7 individuals developed pulmonary disease in both episodes; 2 developed extrapulmonary tuberculosis twice; and 5 presented both forms, 1 in each episode.

Thirty-five patients reported prior treatment for tuberculosis, which could indicate re-infection, reactivation of a latent infection, or inadequate treatment. Approximately one-third of these patients abandoned treatment on the first diagnosis, possibly due to the low educational and social level, despite the controversy of the influence of social and economical status on treatment adherence ${ }^{19}$.

Regarding diagnosis of tuberculosis, direct bacilloscopy was performed in $76.8 \%$ of the cases and was found positive in $63.0 \%$. The choice for direct bacilloscopy may reflect the characteristics of a university hospital where investigation follows a systematic path, or it may reflect an attempt to prevent nosocomial transmission. In another study conducted in Brazili20, direct bacilloscopy was performed in $72.9 \%$ of the cases and was positive in only $23.9 \%$ of them.

Although negative direct bacilloscopy in seropositive patients may looks like a lower risk of transmission, these individuals are generally more immunocompromised and have higher mortality rates ${ }^{21}$. These findings could be related to subdiagnosis of tuberculosis following a negative test and leading to erroneous differential diagnosis, such as pneumocystosis and Kaposi's sarcoma.

Diagnosis of tuberculosis was accomplished first through direct bacilloscopy $(39.5 \%)$, and second through specimen culture $(29.9 \%$ ) (Table 6). Specimen culture was undertaken for 209 patients $(36.0 \%)$ and was positive in $68.4 \%$. Although less specific than specimen culture, direct bacilloscopy is a reliable test with a

Table 5 - Aids/tuberculosis comorbidity cases by clinical form of tuberculosis HCFMUSP, 1989 to 1997.

\begin{tabular}{|c|c|c|c|c|c|}
\hline \multirow[t]{2}{*}{ year } & \multicolumn{2}{|c|}{ Extrapulmonary } & \multicolumn{2}{|c|}{ Pulmonary } & \multirow{2}{*}{$\begin{array}{c}\text { Total } \\
\mathrm{N}\end{array}$} \\
\hline & $\mathrm{N}$ & $\%$ & $\mathrm{~N}$ & $\%$ & \\
\hline 1989 & 13 & 33.3 & 26 & 66.7 & 39 \\
\hline 1990 & 19 & 45.2 & 23 & 54.8 & 42 \\
\hline 1991 & 15 & 36.6 & 26 & 63.4 & 41 \\
\hline 1992 & 28 & 50.0 & 28 & 50.0 & 56 \\
\hline 1993 & 11 & 25.6 & 32 & 74.4 & 43 \\
\hline 1994 & 15 & 40.5 & 22 & 59.5 & 37 \\
\hline 1995 & 44 & 35.5 & 80 & 64.5 & 124 \\
\hline 1996 & 15 & 30.6 & 34 & 69.4 & 49 \\
\hline 1997 & 50 & 35.2 & 92 & 64.8 & 142 \\
\hline Total & 210 & 36.6 & 363 & 63.4 & 573 \\
\hline
\end{tabular}

high positive preditive value $(98.4 \%$ in sputum samples and $96.4 \%$ in bronchoalveolar lavage samples) for tuberculosis infection ${ }^{22}$. Despite the challenges at our hospital, only $3.5 \%$ of tuberculosis cases had the diagnosis clarified at necropsy (data found in notification forms). Findings of 50.0\% of cases diagnosed postmortem may reflect an inferior investigation ${ }^{8}$.

Diagnosis of AIDS was reached according to the Caracas criteria in $51.2 \%$ of the cases and according to the Centers of Disease Control criteria in $39.0 \%$; in $9.8 \%$ of the cases the diagnostic criteria were unknown. The findings following the use of Caracas criteria for diagnosis of AIDS are supported by the findings of oral candidiasis and tuberculosis, since the diseases are most frequently related to AIDS in Brazil.

\section{CONCLUSIONS}

Comorbid cases of AIDS/tuberculosis have a higher rate of extrapulmonary clinical manifestation, probably due to the immunosuppression inflicted by HIV. Further studies are needed to describe the immune status (lymphocytes, viral load, etc.) that accompanies mycobacterial infection.

Although atypical, tuberculosis in association with AIDS is still a transmissible, treatable, and preventable disease. Therefore, early diagnosis and

Table 6 - Aids/tuberculosis comorbidity cases by diagnosis exam of tuberculosis - HCFMUSP, 1989 to 1997.

\begin{tabular}{lrr}
\hline Exam & $\mathrm{N}$ & $\%$ \\
\hline direct bacilloscopy & 186 & 39.5 \\
specimen culture & 141 & 29.9 \\
clinical/radiologic & 90 & 19.1 \\
pathological & 30 & 6.4 \\
necropsy & 20 & 4.2 \\
immunohistochemistry & 4 & 0.8 \\
Total * & 471 & 100.0 \\
$*$ 102 patients with unknown diagnostic exam
\end{tabular}


treatment of AIDS patients also infected by $M$. tuberculosis can lead to lower mortality rates. The complex treatment, leading to poor adhesion, may be one of the factors contributing to the maintenance of high rates of incidence of the AIDS/tuberculosis comorbidity. A study conducted by the Brazilian National Health Department ${ }^{19}$ identifies the lowest social class as at risk for nonadherence to medical treatment. This is the same social class that frequently attends at our hospital's medical facilities and is at risk for AIDS/tuberculosis comorbidity. The low schooling level and professional qualification of this group reinforces the need for a multiprofessional team and a special project to enhance early diagnosis and adherence to established medical treatment. The study is based on reported files and computerized laboratory data research. The investigation files of the hospital epidemiology service provided adequate data for the clinical and epidemiological description of comorbid AIDS/tuberculosis cases. Access to computer- ized patient information and laboratory data offered additional information. The survey was conducted without consultation of the patient clinical files, demonstrating the viability of studies developed through research of routine data collected by hospital epidemiological surveillance services.

\section{ACKNOWLEDGEMENT}

We would like to thank Maria Mastrobuono Nesti for her essential help.

\section{RESUMO}

SONG ATW e col. - Aspectos clínicos e epidemiológicos da comorbidade AIDS/tuberculose. Rev. Hosp. Clín. Fac. Med. S. Paulo 58(4):207-214, 2003.

Frente à importância da comorbidade AIDS/tuberculose no mundo e especialmente no Brasil, este estudo foi realizado para descrever os aspectos clínicos e epidemiológicos dos casos de comorbidade notificados pelo Serviço de Epidemiologia do Hospital das Clínicas of the Universidade de São Paulo identificados de 1989 à 1997.

MÉTODOS: Foram utilizados bancos de dados contendo informações de todos os casos notificados de AIDS/tuberculose assistidos pelo hospital.

RESULTADOS: Durante o período estudado, foram identificados 559 pacientes com a comorbidade. Os fatores de risco para AIDS incluiam principalmente contato heterossexual $(38,9 \%)$, seguido por uso de drogas endovenosas $(29,3 \%)$, e contato homossexual/bissexual (23,2\%). Quanto aos aspectos clínicos, houve maiores índices de tuberculose extrapulmonar em comparação com tuberculose isoladamente. As unidades ambulatoriais mostraram aumento das notificações de AIDS durante o período. A descrição epidemiológica mostrou um declí- 
nio na relação masculino/feminino, predomínio do acometimento da faixa etária de 20 a 39 anos e de indivíduos com escolaridade menor que 8 anos de estudo, com baixa qualificação profissional.

CONCLUSÃO: As altas taxas de casos de comorbidade AIDS/tuberculose indicam a necessidade de melhor atendimento desses pacientes, objetivando a detecção precoce da comorbidade. Tendo em vista as más condições sócio-econômicas da maioria da população deste hospital, uma melhor atenção visa ao aumento da aderência ao tratamento, e por consequência, menores custos sociais.

DESCRITORES: AIDS. Tuberculose. Comorbidade. Epidemiologia. Vigilância epidemiológica.

\section{REFERENCES}

1. MAYAUD C, CADRANEL $\mathrm{J}$ - Tuberculosis in AIDS: past or new problems? Thorax 1999; 54 (7): 567-71.

2. ROSE D N, VETTER S, GUTMAN A - Diagnosis and management of tuberculosis in patients with HIV infection. Mount Sinai J Med 1998; 65 (1): 14-20.

3. PERLMAN DC, EL-HELOU P, SALOMON N - Tuberculosis in patients with human immunodeficiency virus infection. Semin Respir Infect 1999; 14 (4): 344-52.

4. SHAFER RW, EDLIN BR - Tuberculosis in patients infected with human immunodeficiency virus: Perspective on the past decade. Clin Infect Dis 1996; 22: 683-704.

5. CHINTU C, MWINGA A - An African perspective on the threat of tuberculosis and HIV/AIDS - can despair be turned to hope? Lancet 1999; 353 (9157): 997.

6. GUIMARAES MD - Estudo temporal das doenças associadas a AIDS no Brasil, 1980-1999. Cad Saúde Pública 2000; 16 (Suppl 1): 21-36.

7. SÃO PAULO, Secretaria de Estado da Saúde. Incidência Média de AIDS por unidade da Federação e período de diagnóstico. Boletim Epidemiológico do Programa de DST-AIDS, 1998, ano XVI; número 02.

8. SMITH MB, BOYARS MC, VEASEY S et al. - Generalized tuberculosis in the acquired immune deficiency syndrome. Arch Pathol Lab Med 2000; 124 (9): 1267-74.

9. ZUMLA A, MALON P, HENDERSON J et al. - Impact of HIV infection on tuberculosis. Postgrad Med J 2000; 76 (895): 25968 .
10. BRASIL, Ministério da Saúde - Manual de Normas para Controle da Tuberculose . Brasília, Ministério da Saúde, 1995.

11. In: http://www.AIDS.gov.br/udtv/link203.htm

12. KEIZER ST, LANGENDAM MM, VAN DEUTEKOM H et al. How does tuberculosis relate to HIV positive and HIV negative drug users? J Epidemiol Community Health 2000; 54 (1): 64-8.

13. SZWARCWALD CL, BASTOS FI, ESTEVES MA et al. - A disseminação da epidemia da AIDS no Brasil, no período de 1987 1996: uma análise espacial. Cad Saúde Pública 2000; 16 (1): 7-20.

14. SÃO PAULO, Secretaria de Estado da Saúde. Recomendações e condutas após exposição ocupacional de profissionais de saúde. Boletim Epidemiológico do Programa de DST-AIDS, 1999, ano XVII, número 01.

15. GOMEZ M A, FERNANDEZ DM, OTERO JF et al. - The shape of the HIV/AIDS epidemic in Puerto Rico. Rev Panamer Salud Publica 2000; 1 (6): 377-83.

16. NGOM A, AKA-DANGUY E, KOFFI N et al. - Epidemiology of tuberculosis in Abidjan, Ivory Coast: effects of HIV infection. Med Trop 1999; 59 (2): 165-8.

17. SÃO PAULO, Secretaria de Estado da Saúde. Vigilância de HIV em gestantes e crianças expostas. Boletim Epidemiológico do Programa de DST-AIDS, 2000, ano XVIII; número 02.

18. RAVIGLIONE MC, O'BRIEN RJ - Tuberculosis. In: FAUCI A S, BRAUNWALD E, ISSELBACHER KJ et al. - Principles of Internal Medicine, $14^{\text {th }}$ ed. 1998, v. 1, p. 1004-1114. 
Clinical and epidemiological features of aids/tuberculosis comorbidity Song ATW et al.

19. BRASIL, Ministério da Saúde - Secretaria de Políticas de Saúde. Coordenação Nacional de DST e AIDS. Aderência ao Tratamento por Anti-retrovirais em Serviços Públicos no Estado de São Paulo. Brasília, Ministério da Saúde, 2000.

20. KERR-PONTES LR, OLIVEIRA FA \& FREIRE CA - Tuberculose associada a AIDS: situação de região do Nordeste brasileiro. Rev Saúde Pública 1997; 31 (4): 323-9.
REV. HOSP. CLÍN. FAC. MED. S. PAULO 58(4):207-214, 2003

21. COLEBUNDERS R, BASTIAN I - A review of the diagnosis and treatment of smear-negative pulmonary tuberculosis. Int $\mathbf{J}$ Tuberc Lung Dis 2000; 4 (2): 97-107.

22. CONDE MB, FIGUEIRA CM, MORAES R et al. - Predictive value of the acid fast smear for detection of Mycobacterium tuberculosis in respiratory specimens in a reference center of HIV/AIDS in Rio de Janeiro, Brazil. Mem Inst Oswaldo Cruz 1999; 94 (6): 787-90. 